\title{
ASSESSMENT OF INOCULA AND N- REMOVAL PERFORMANCE OF ANAEROBIC AMMONIUM OXIDATION (ANNAMOX) FOR THE TREATMENT OF “OLD” LANDFILL LEACHATES
}

\author{
He Yan \\ Zhou Gongming \\ Zhao Youcai \\ Feng Guoguang \\ Tongji University, China
}

\begin{abstract}
Three kinds of seeding sludge, i.e. conventional activated sludge, anaerobic granular sludge and the nitrifying activated sludge from the nitritation reactor treating aged leachates were evaluated in batch mode to screen the optimized inoculum for the rapid start-up of ANAMMOX reactor. The feasibility of the ANAMMOX process for the treatment of aged leachates was also investigated in a modified upflow anaerobic sludge blanket (UASB, $0.05 \mathrm{~m}^{3}$ ). The batch experiments revealed that the nitrifying activated sludge from the nitritation reactor could respectively achieve the NRR (nitrogen removal rate) of $0.0365 \mathrm{~kg} \mathrm{~N} /\left(\mathrm{m}^{3} . \mathrm{d}\right.$ ) and the ARR (ammonium removal rate) of 0.013 $\mathrm{kg} \mathrm{N} /\left(\mathrm{m}^{3} . \mathrm{d}\right)$ on day 12 , which were greatly higher than those of the other two tested sludge samples. The mixture of the aforementioned nitrifying activated sludge and anaerobic granular sludge was established as an effective inoculum for the prompt startup of ANAMMOX reactor. The maximum total nitrogen removal rate of $0.826 \mathrm{~kg}$ $\mathrm{N} /\left(\mathrm{m}^{3} . \mathrm{d}\right)$ could be obtained for the treatment of "old" leachates under NLR (nitrogen loading rate) of $1.028 \mathrm{~kg} \mathrm{~N} /\left(\mathrm{m}^{3} . \mathrm{d}\right)$. It is concluded that the $\mathrm{N}$-removal performance of ANAMMOX process is still to be improved for actual engineering application to aged landfill leachates.
\end{abstract}

\section{KEYWORDS}

"Old" landfill leachates; Inocula; Start-up; ANAMMOX.

\section{INTRODUCTION}

Leachate from "old" landfills are often rich in ammonium nitrogen and deficient in biodegradable carbon source. Hence, conventional biological nitrogen removal processes are always ineffective for the treatment of "old" leachates because of severe nutritional imbalance and the toxicity of free ammonia (FA) [1]. The widely-used ammonia stripping process is also unfeasible in treating "old" leachates due to its strong buffering capability. Therefore, it becomes a big challenge to remove high-strength 
ammonium nitrogen economically and effectively for the long-term landfill management.

Recently, the new processes based on partial nitrification of ammonium to nitrite coupling with anaerobic ammonium oxidation (ANAMMOX) are considered a promising option for treating ammonium-laden and low $\mathrm{C} / \mathrm{N}$ ratio leachates, for the combined process allows over $50 \%$ of the oxygen to be saved, no exogenous electron donor is needed and less sludge is produced [2]. The feasibility of stable nitrite accumulation from aged leachates has been confirmed [3]. However, the main limitations inherent to the ANAMMOX process are requirement of a long start-up period and instability mainly because of slow growth rates and sensitivity of ANAMMOX bacteria [4-7]. Therefore, appropriate seeding sludge must be selected and cultured to facilitate the rapid start-up and stability of ANAMMOX reactor. Several kinds of sludge samples, including conventional activated sludge[8-9],nitrifying activated sludge[10], anaerobic granular sludge[11] and the mixed microbial consortium from different sludge $[4,12]$, were mainly used as inocula for ANAMMOX process. However, the ANAMMOX capacities of aforementioned sludge were not consistently confirmed [6, 10-12]. Moreover, few relative researches on the treatment of "old" leachates have been documented.

In this study, three kinds of seeding sludge, i.e. conventional activated sludge, anaerobic granular sludge and the nitrifying activated sludge from the nitritation reactor treating aged leachates were evaluated in batch mode to screen the optimized inoculum for the rapid start-up of ANAMMOX reactor. The applicability of the ANAMMOX process for the treatment of aged leachates was also investigated.

\section{MATERIAL AND METHODS}

\subsection{Feeding media and seeding sludge}

The raw leachates used in this experiment were drained from a 9-year-old closed landfill compartment in Shanghai Laogang Refuse Landfill. The effluent from the preceding nitritation reactor was diluted by tap water and the raw leachates to the desired level of ammonium and nitrite, which was used as feeding media. The averaged characteristics of the leachates are given in Table 1. The activated sludge (AS) was taken from Shanghai QuYang sewage treatment plant. The anaerobic granular sludge (AnGS) was taken from a brewery wastewater treatment plant. The nitrifying activated sludge (NAS) was collected from the nitritation reactor. Each seed sludge sample was adjusted to approximately $3000 \mathrm{mg} / \mathrm{L}$ VSS (volatile suspended solids). The seeding sludge for the subsequent ANAMMOX reactor was the mixture of the nitrifying activated sludge from the nitritation reactor and the aforementioned anaerobic granular sludge. The sludge concentration in the reactor after inoculation was about $3500 \mathrm{mg} / \mathrm{L}$. 
Table 1. Characteristics of the leachates.

\begin{tabular}{|c|c|c|c|c|c|c|c|}
\hline Parameters & CODcr & $\begin{array}{l}\text { BOD } \\
5\end{array}$ & $\begin{array}{l}\mathrm{NH}_{4}^{+}- \\
\mathrm{N}\end{array}$ & $\mathrm{NO}_{2}^{-}-\mathrm{N}$ & $\begin{array}{l}\mathrm{NO}_{3}{ }^{-}- \\
\mathrm{N}\end{array}$ & $\mathrm{pH}$ & Alkalinity \\
\hline Raw leachate & 2200 & 250 & 2900 & $\begin{array}{c}\text { negligibl } \\
\mathrm{e}\end{array}$ & 50 & $5^{8.1}$ & 12000 \\
\hline $\begin{array}{l}\text { The nitritation } \\
\text { effluent }\end{array}$ & 1750 & 102 & 1080 & 1560 & 80 & $2^{6.9}$ & 420 \\
\hline
\end{tabular}

Notes: the unit of the above parameters is $\mathrm{mg} / \mathrm{L}(\mathrm{pH}$ is exceptional); the alkalinity is expressed as $\mathrm{mg} / \mathrm{L}$ $\mathrm{CaCO}_{3}$

\subsection{Batch tests procedure}

Each sludge sample was diluted to approximately $4000 \mathrm{mg} / \mathrm{L}$ MLSS with the feeding media, and $450 \mathrm{~mL}$ of the mixed liquid was transferred into $600 \mathrm{~mL}$ brownish glass bottles with gas-tight butyl rubber stoppers. $50 \mathrm{~mL}$ of the designed feeding media was added to each bottle to ensure about $50 \mathrm{mg} / \mathrm{L}$ of $\mathrm{NH}_{4}{ }^{+}-\mathrm{N}$ and $\left(\mathrm{NO}_{2}{ }^{-}-\mathrm{N}+\mathrm{NO}_{3}{ }^{-}-\mathrm{N}\right)$, respectively. The air of the headspaces in the bottles was replaced by helium. To each bottle, one glass tube connecting one modified perfusion tube and one air duct immersing into a bottle filled with saturated $\mathrm{NaCl}$ passed through each butyl rubber cap for effluent discharge and gas discharge, respectively. Each sample was incubated at $35^{\circ} \mathrm{C}$ in the biochemical incubator covered with aluminum foil. The conditioned water phase was mixed moderately by a magnetic stirring apparatus. Water samples were periodically taken from the water phase in the bottles by siphoning. The concentration of $\mathrm{NH}_{4}{ }^{+}-\mathrm{N}, \mathrm{NO}_{2}{ }^{-}-\mathrm{N}$ and $\mathrm{NO}_{3}{ }^{-}-\mathrm{N}$ were periodically monitored during the incubation. The media in the bottles was exchanged with a fresh one using a syringe, without allowing air to enter.

\subsection{ANAMMOX reactor setup and operation}

A UASB reactor with an effective volume of $0.05 \mathrm{~m}^{3}$ was used as the ANAMMOX reactor. This cylinder reactor was of $180 \mathrm{~cm}$ height and $20 \mathrm{~cm}$ diameter. The reactor temperature was controlled by recirculating thermostated water through a tube placed around the reactor. The UASB reactor was covered with a gobo and gas production was measured using a wet-type gasmeter.

\subsection{Analytical procedures}

All chemical analyses were performed in accordance with standard methods [13]. Daily measurement of $\mathrm{pH}$ was conducted with a portable electrode. The main nitrogen speciation was mainly inorganic nitrogen (ammonium, nitrite and nitrate) and organic nitrogen was negligible by analysis of raw leachates and effluents. Therefore, the total nitrogen (TN) and COD were only monitored periodically. 


\section{RESULTS}

\subsection{Screening of seeding sludge}

As for the nitrifying activated sludge, the simultaneous removal of ammonium and nitrite and nitrate was clearly observed on day 12 , indicating occurrence of the ANAMMOX reaction. The nitrogen removal rate (NRR) and ammonium removal rate (ARR) were respectively $0.0405 \mathrm{kgN} /\left(\mathrm{m}^{3} . \mathrm{d}\right)$ and $0.016 \mathrm{kgN} /\left(\mathrm{m}^{3} . \mathrm{d}\right)$ on day 14 (see Figurel).During 14 days of operation, the ANAMMOX activity of the activated sludge could be neglected(ARR was $0.0053 \mathrm{~kg} \mathrm{~N} /\left(\mathrm{me}^{3} . \mathrm{d}\right)$ ). In the case of the anaerobic granular sludge, strong ammonification and denitrification occurred and no ANAMMOX reaction was detected within 14 days of incubation. Taking into account the best ANAMMOX capacity of the nitrifying activated sludge and easy granulation, the mixture of nitrifying activated sludge and anaerobic granular sludge was thus used as inoculum for following the ANAMMOX reactor experiments.

\subsection{Start-up of the ANAMMOX reactor}

The ANNAMOX reactor was started-up by inoculating $0.014 \mathrm{~m}^{3}$ of the nitrifying activated sludge from the nitritation reactor and $0.021 \mathrm{me}^{3}$ of the aforementioned anaerobic granular sludge. The operational condition was set at HRT of 2 days and $35{ }^{\circ} \mathrm{C}$. The nitritation reactor effluent at steady stages was diluted by tap water and the raw leachates according to the designed influent level of ammonium and nitrite of the ANAMMOX reactor. In the first five stages, the influent nitrite/ammonium ratio of the ANAMMOX reactor was around 1 and the inlet concentrations of ammonium and nitrite were increased stepwise from around $50 \mathrm{mg} / \mathrm{L}$ to $250 \mathrm{mg} / \mathrm{L}$ (Level 1: $50 \mathrm{mg} / \mathrm{L}$; Level 2: $100 \mathrm{mg} / \mathrm{L}$; Level 3: $150 \mathrm{mg} / \mathrm{L}$; Level 4:200 mg/L; Level 5: $250 \mathrm{mg} / \mathrm{L}$ ). In the sixth stage (Level 6), the inlet ammonium concentration was elevated at around 500 $\mathrm{mg} / \mathrm{L}$ to facilitate the growth of ANAMMOX bacteria and inhibit the activity of denitrifying bacteria. The inlet nitrite concentration was still kept at about $250 \mathrm{mg} / \mathrm{L}$ considering the inhibitory effect of high-level nitrite on the ANAMMOX process [14]. The influent concentration of nitrate was negligible compared with the level of nitrite and thus was not assigned quantitatively. 

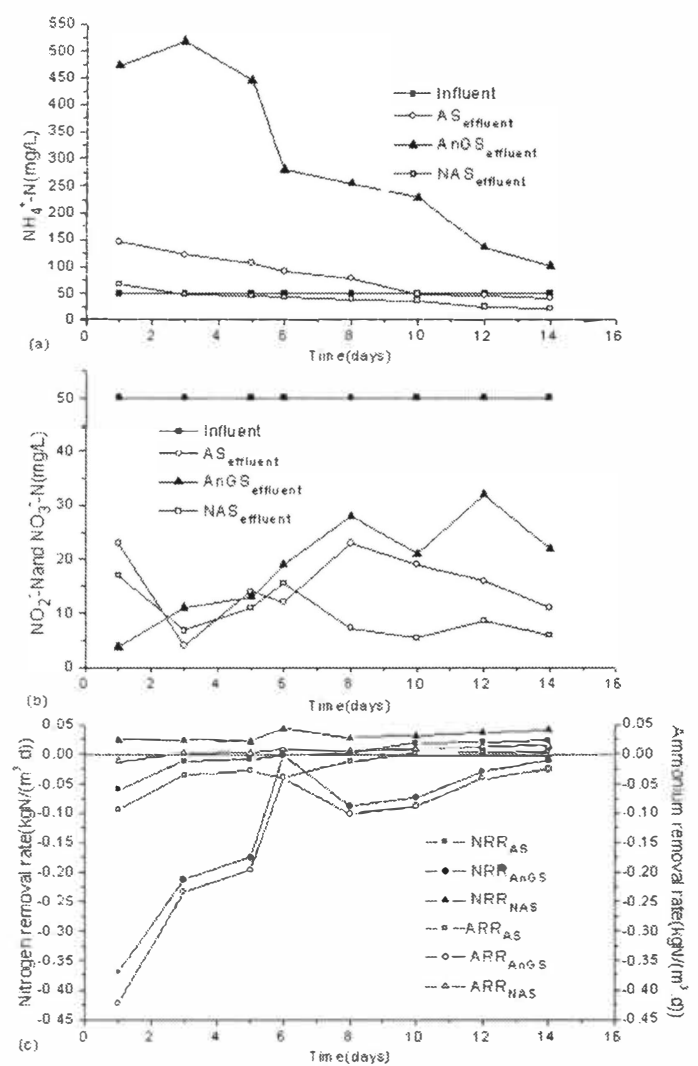

Figure 1. Comparisons of N-removal performance of the activated sludge (AS), anaerobic granular sludge (AnGS) and nitrifying activated sludge (NAS) during 14 days of incubation.

The concentration profiles of soluble nitrogen compounds during start-up of the ANAMMOX reactor are depicted in Figure 2. Figure 2 shows that the N-removal performance was improved rapidly in the initial 21 days and then the corresponding elimination efficiency of ammonium and nitrite were kept at about $80 \%$ and $90 \%$. Following the stepwise increase of the inlet concentration in latter stages, the removal efficiency of ammonium and nitrite in each steady stage were up to $80 \%$ and $90 \%$, respectively. The nitrate removal percentage was kept at about $60 \%$ in the first three levels and then decreased to about $40 \%$. However, when the inlet concentration of ammonium was increased at about $500 \mathrm{mg} / \mathrm{L}$, the $\mathrm{N}$-removal performance of the reactor became worsening.

The ANAMMOX process indubitably occurred in the reactor by analysis of the experimental results (shown in Table 2). All data listed in Table 2 refer to the mean of each steady stage. The maximum total nitrogen elimination rate of $0.229 \mathrm{~kg} \mathrm{~N} /\left(\mathrm{m}^{3} . \mathrm{d}\right)$ was obtained at Level 5 . The relatively high influent nitrate significantly affected the 
ratios of $\Delta \mathrm{NO}_{2}{ }^{-}-\mathrm{N} / \Delta \mathrm{NH}_{4}{ }^{+}-\mathrm{N}$ and $\left(\Delta \mathrm{NO}_{2}{ }^{-}-\mathrm{N}+\Delta \mathrm{NO}_{3}{ }^{-}-\mathrm{N}\right) / \Delta \mathrm{NH}_{4}{ }^{+}-\mathrm{N}$ due to low influent concentration of ammonium and nitrite at Level 1. Therefore, the corresponding average ratios of $\Delta \mathrm{NO}_{2}{ }^{-}-\mathrm{N} / \Delta \mathrm{NH}_{4}{ }^{+}-\mathrm{N}$ and $\left(\Delta \mathrm{NO}_{2}{ }^{-} \mathrm{-N}+\Delta \mathrm{NO}_{3}{ }^{-}-\mathrm{N}\right) / \Delta \mathrm{NH}_{4}{ }^{+}-\mathrm{N}$ were calculated as 1.12 and 1.24 during start-up of the ANAMMOX reactor (Level 1 was exceptional). However, the exact percentage of nitrite and nitrate utilized by the denitrifying process is needed for further study.

Table 2. Conversion of soluble nitrogen compounds during start-up of the ANAMMOX reactor.

\begin{tabular}{lllllll}
\hline Level & 1 & 2 & 3 & 4 & 5 & 6 \\
\hline Total nitrogen removal rate $\left(\mathrm{kg} \mathrm{N} /\left(\mathrm{m}^{3} . \mathrm{d}\right)\right)$ & 0.052 & 0.097 & 0.140 & 0.197 & 0.229 & - \\
Ammonium removal rate $\left(\mathrm{kg} \mathrm{N} /\left(\mathrm{m}^{3} . \mathrm{d}\right)\right)$ & 0.021 & 0.043 & 0.062 & 0.084 & 0.104 & - \\
Nitrite removal rate $\left(\mathrm{kg} \mathrm{N} /\left(\mathrm{m}^{3} \cdot \mathrm{d}\right)\right)$ & 0.025 & 0.048 & 0.070 & 0.094 & 0.117 & - \\
Nitrate removal rate $\left(\mathrm{kg} \mathrm{N} /\left(\mathrm{m}^{3} \cdot \mathrm{d}\right)\right)$ & 0.006 & 0.006 & 0.008 & 0.009 & 0.008 & - \\
$\Delta \mathrm{NO}_{2}-\mathrm{N} / \Delta \mathrm{NH}_{4}{ }^{+}-\mathrm{N}$ & 1.19 & 1.12 & 1.13 & 1.12 & 1.12 & - \\
$\left(\Delta \mathrm{NO}_{2}{ }^{-}-\mathrm{N}+\Delta \mathrm{NO}_{3}{ }^{-}-\mathrm{N}\right) / \Delta \mathrm{NH}_{4}{ }^{+}-\mathrm{N}$ & 1.48 & 1.28 & 1.26 & 1.23 & 1.20 & - \\
\hline
\end{tabular}

\subsection{N-removal performance of the ANAMMOX process}

Based on the research on the partial nitritation with "old"landfill leachates, a high nitrite/ammonium ratio of 1.40-1.68 was obtained [3]. The nitrite surplus in the effluent of the preceding nitritation reactor can be balanced by adding raw leachates directly to the ANAMMOX reactor. Therefore, the ANAMMOX process becomes bottleneck for the potential of nitrogen removal of the combined process. The $\mathrm{N}$-removal performance of the ANAMMOX reactor was thus mainly evaluated.

Following the above start-up, the operation of the ANAMMOX reactor was restored by adding $0.002 \mathrm{me}^{3}$ of the nitrifying activated sludge from the nitritation reactor and 0.003 $\mathrm{me}^{3}$ of the above-mentioned anaerobic granular sludge. The operational condition was set at HRT of 2 days and $35^{\circ} \mathrm{C}$. The inlet concentrations of ammonium and nitrite were increased stepwise from around $100 \mathrm{mg} / \mathrm{L}$ to $250 \mathrm{mg} / \mathrm{L}$. Enough time was allowed to achieve a stable operation at each stage. The results were similar to that of the above start-up period (data not shown). After the restoration of the ANAMMOX reactor, HRT was reduced in steps to investigate the $\mathrm{N}$-removal performance of the ANAMMOX reactor at the influent concentrations of ammonium and nitrite of about $250 \mathrm{mg} / \mathrm{L}$. When the HRT was reduced to $0.3 \mathrm{~d}$, the N-removal efficiency of the reactor decreased rapidly. The removal efficiency of ammonium and nitrite decreased respectively to $28 \%$ and $40 \%$ after 8 days of consecutive operation. Figure 3 presents the $\mathrm{N}$-removal performance of the ANAMMOX reactor at HRTs of $2 \mathrm{~d}$ (Level 1), $1.5 \mathrm{~d}$ (Level 2), $1.0 \mathrm{~d}$ (Level 3) and $0.5 \mathrm{~d}$ (Level 4). All data listed in Figure 3 refer to the mean of each steady stage. 

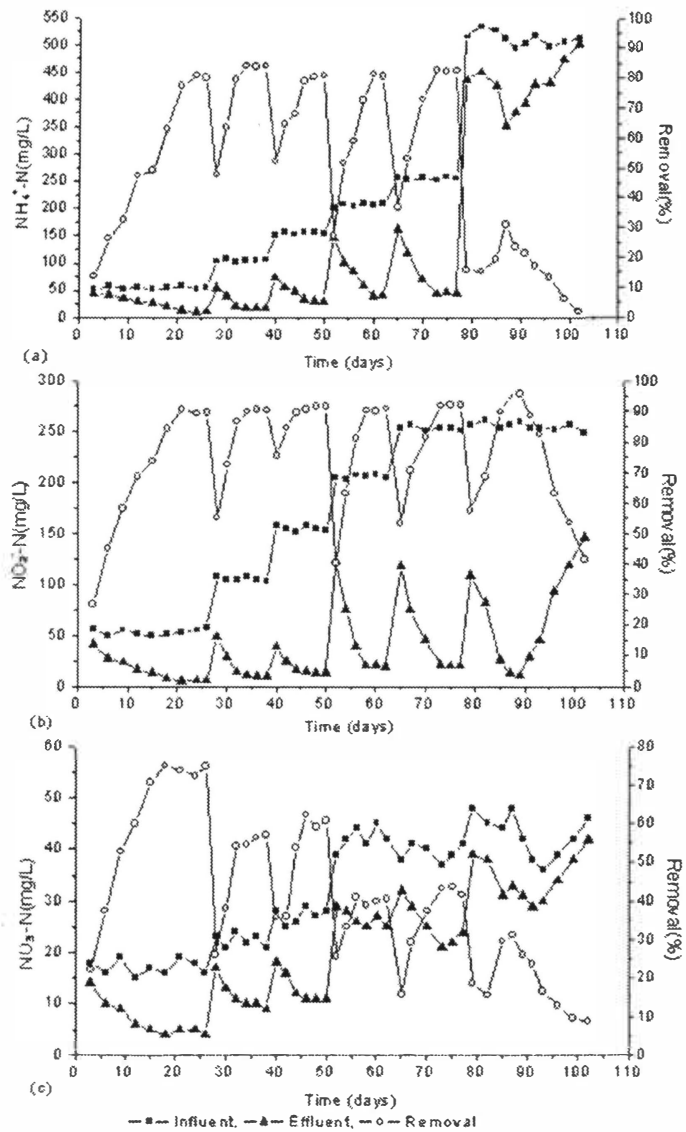

Figure 2. Profile of nitrogen removal during start-up of the ANAMMOX reactor seeded with the mixture of the nitrifying activated sludge and the anaerobic granular sludge.

As shown in Figure 3, the total nitrogen elimination rate increased from $0.236 \mathrm{~kg}$ $\mathrm{N} /\left(\mathrm{m}^{3}\right.$.d) to $0.826 \mathrm{~kg} \mathrm{~N} /\left(\mathrm{m}^{3}\right.$.d $)$ with the stepwise reduction of HRT from $2 \mathrm{~d}$ to $0.5 \mathrm{~d}$. However, the optimal HRT was $1.5 \mathrm{~d}$ in terms of the removal efficiency of ammonium and nitrite. The corresponding removal efficiency of ammonium and nitrite was $90.3 \%$ and $96.5 \%$ at Level 2 . To sum up, the operation of the ANAMMOX reactor was almost stable in terms of nitrogen removal efficiency during the stepwise reduction of HRT from $2 \mathrm{~d}$ to $1.0 \mathrm{~d}$. The averaged removal efficiency of ammonium, nitrite and nitrate was $86.9 \%, 94.7 \%$ and $40.1 \%$ in the first three levels. The removal efficiency of ammonium, nitrite and nitrate decreased to $76.1 \%, 81.6 \%$ and $19.5 \%$ at HRT of $0.5 \mathrm{~d}$. 


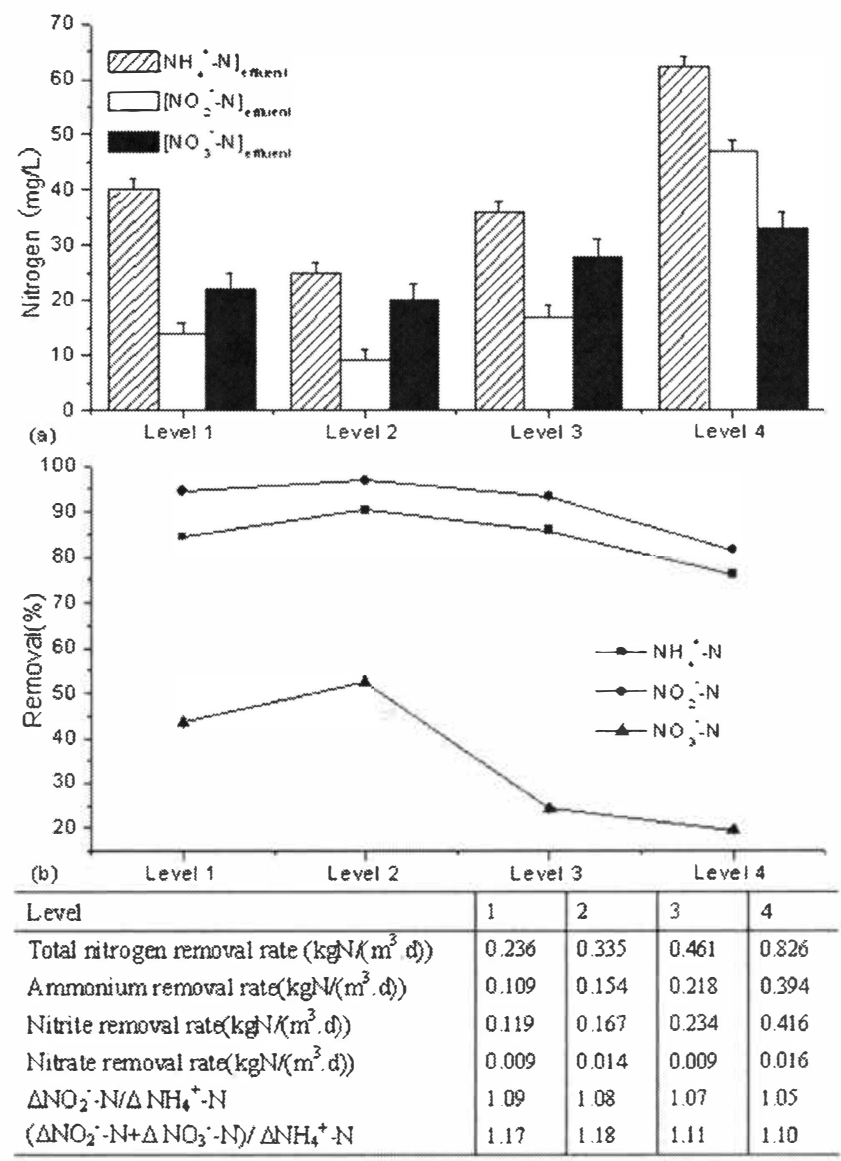

Figure 3. N-removal performance of the ANAMMOX reactor at HRTs of $2 d$ (Level 1), $1.5 d$ (Level 2), $1.0 d$ (Level 3) and $0.5 d$ (Level 4). Error bars represent: average $\pm S . D$.

\section{DISCUSSIONS}

In the literature different kinds of sludge are used as inocula for ANAMMOX reactor and fairly disparate observations are found concerning the ANAMMOX performance of seeding sludge. Pathak's experiments [12] show that ANAMMOX bacteria were absent in the bioreactor inoculated with anaerobic granules, whereas [11] indicates the opposite.[10] report that it is feasible to start up ANAMMOX bioreactor seeding with the nitrifying sludge, whereas Tsushima's work [6] demonstrates the bad AMAMMOX potential of the nitrifying sludge. Our research shows that compared with the nitrifying activated sludge and conventional activated sludge, anaerobic granular sludge is not an ideal inocula in terms of rapid start-up of ANAMMOX reactor. These reported disagreements in the ANAMMOX activity of different seeding sludge can be attributed 
to the differences of operating conditions, e.g. biomass concentrations, the acclimatization of the microorganisms and wastewater characteristics.

ANAMMOX is defined as the concomitant decreases of nitrite and ammonium in the anaerobic conditions. Based on the experimental results, the existence of the ANAMMOX reaction in the modified UASB was well validated and the start-up period is reduced significantly when seeding the mixture of the nitrifying activated sludge from the preceding nitritation reactor and the anaerobic granular sludge. It is well established that ANAMMOX bacteria share many physiological characteristics common to nitrifiers. Some nitrifiers like Nitrosomonas europaea and Nitrosomonas eutroha that oxidize ammonia to nitrite aerobically, can perform ANAMMOX activity, and oxidize ammonia using nitrite as electron acceptor under anaerobical conditions [15]. Additionally, many nitrifiers have been detected in ANAMMOX sludge [16]. The metabolic diversity of ammonia oxidizers offers a possibility to use nitrifying activated sludge as seeding sludge for ANAMMOX reactor [10]. The experimental results showed that the mixture of the nitrifying activated sludge and anaerobic granular sludge could be used as inoculum for ANAMMOX reactor and also accelerate the start-up of the reactor, which further confirmed the diversity of metabolic pathway of ammonium oxidizers.

Although the N-removal performance of the reactor became worsening at the inlet ammonium concentration of $500 \mathrm{mg} / \mathrm{L}$, the total nitrogen elimination rate could be increased by the reduction of hydraulic retention time, i.e. the increase of hydraulic load. The operation of the ANAMMOX reactor was almost stable in terms of nitrogen removal efficiency during the stepwise reduction of HRT from $2 \mathrm{~d}$ to $1.0 \mathrm{~d}$. The decrease of the nitrogen removal efficiency at HRT of $0.5 \mathrm{~d}$ and the worsening $\mathrm{N}$ removal performance at HRT of $0.3 \mathrm{~d}$ may be interpreted by the fact that the total nitrogen load rate exceeded the specific ANAMMOX capacity. When the maximum specific ANAMMOX capacity was exceeded, some granules broke apart and thus the settleability properties of the sludge became worsening. The gas bubbles inside the granules or stuck to their surfaces induce the flotation of the biomass and the consequent biomass washout occurred due to the deteriorated sludge settling properties, which could account for significant fine sludge scraps observed in the effluent at HRT of $0.3 \mathrm{~d}$. Therefore, the destabilization of the ANAMMOX reactor was observed due to the notable loss of biomass. The factors affecting the stable operation of the ANAMMOX reactor as well as the nitrogen conversion mechanism in this reactor are still to be studied with the aid of other techniques such as molecular biology methods.

\section{CONCLUSIONS}

This paper aimed to establish the protocol of rapid start-up of ANAMMOX reactor and investigate the feasibility of the ANAMMOX process for the treatment of "old" landfill leachates. Based on the experimental results, some specific conclusions might be drawn as follows:

(1) The nitrifying activated sludge from the nitritation reactor could achieve the nitrogen removal rate of $0.0365 \mathrm{~kg} \mathrm{~N} /\left(\mathrm{m}^{3} . \mathrm{d}\right)$ and the ammonium removal rate of $0.013 \mathrm{~kg} \mathrm{~N} /\left(\mathrm{m}^{3} . \mathrm{d}\right)$ on day 12 , which were greatly higher than those of the activated sludge and anaerobic granular sludge. 
(2) The mixture of the nitrifying activated sludge from the nitritation reactor and anaerobic granular sludge was established as an effective inoculum for the prompt start-up of ANAMMOX reactor.

(3) The maximum total nitrogen removal rate of $0.826 \mathrm{~kg} \mathrm{~N} /\left(\mathrm{m}^{3} . \mathrm{d}\right)$ could be obtained for the treatment of "old" leachates under nitrogen loading rate of 1.028 $\mathrm{kg} \mathrm{N} /\left(\mathrm{m}^{3} . \mathrm{d}\right)$. The optimal HRT was $1.5 \mathrm{~d}$ in terms of the removal efficiency of ammonium and nitrite.

(4) Further research is necessary to increase the N-removal capacity of the ANAMMOX process and avoid the washout of the biomass for actual engineering application to aged landfill leachates.

\section{ACKNOWLEDGEMENT}

This work was carried out as part of the "Wastewater Treatment and Management" project under the Asian Regional Research Programme on Environmental Technology (ARRPET) funded by the Swedish International Development Cooperation Agency (Sida) (No.0400239008).

\section{REFERENCES}

[1] Li, X.Z., Zhao, Q.L., 2003. Recovery of ammonium-nitrogen from landfill leachate as a multi-nutrient fertilizer. Ecological Engineering.20, 171-181.

[2] Jetten,M.S.M., Horn, S.J., van Loosdrecht, M.C.M., 1997. Towards a more sustainable wastewater treatment system. Water Sci.Technol.35, 171-179.

[3] He, Y., Zhou, G.M., Zhao, Y.C., 2007. Nitrification with high nitrite accumulation for the treatment of "Old" landfill leachates. Environmental Engineering Science.24 (8), 1084-1094.

[4] Chamchoi, N., Nitisoravut, S., 2007. Anammox enrichment from different conventional sludges.Chemosphere.66, 2225-2232.

[5] Dapena-Mora,A.,Campos,J.L.,MosqueraCorral,A.,Jetten,M.S.M.,Mendez,R.,2004.Stability of the ANAMMOX process in a gas-lift reactor and a SBR. Journal of Biotechnology.110, 159-170.

[6] Tsushima,I.,Ogasawara,Y.,Kindaichi,T.,Satoh,H.,Okabe,S.,2007.Development of high-rate anaerobic ammonium-oxidizing (anammox) biofilm reactors.Water Research.41, 1623-1634.

[7] Van Dongen, U., Jetten, M.S.M., van Loosdrecht, M.C.M., 2001. The SHARONANAMMOX process for treatment of ammonium rich wastewater. Water Sci Technol.44, 153-160.

[8] Dong, X., Tollner, E.W., 2003. Evaluation of anammox and denitrification during anaerobic digestion of poultry manure. Bioresource Technology.86, 139-145.

[9] Isaka, K., Sumino, T., Tsuneda, S., 2007. High nitrogen removal performance at moderately low temperature utilizing anaerobic ammonium oxidation reactions. Journal of Bioscience and Bioengineering. 103(5), 486-490.

[10] Zheng, P., Lin F.M., Hu, B.L., Chen, J.S., 2004a. Strart-up of anaerobic ammonia oxidation bioreactor with nitrifying activated sludge. Journal of Environmental Sciences.16 (1),13-16.

[11] Wang, J.L., Kang, J., 2005. The characteristics of anaerobic ammonium oxidation (ANAMMOX) by granular sludge from an EGSB reactor. Process Biochemistry.40, 1973-1978. 
[12] Pathak, B.K., Kazama, F., Saiki,Y., Sumino, T., 2007. Presence and activity of anammox and denitrification process in low ammonium-fed bioreactors. Bioresource Technology.98, 2201-2206.

[13] American Public Health Association, APHA, 1998. Standard Methods for the Examination of Water and Wastewater. Washington, DC, USA.

[14] Strous, M., Kuenen,J.G.,Jetten,M.S.M.,1999. Key physiology of anaerobic ammonium oxidation. Appl. Environ.Microbiol.65, 3248-3250.

[15] Strous, M., van Gerven, E., Kuenen, J.G., Jetten, M.S.M., 1997. Effiects of aerobic and microaerobic conditions on anaerobic ammonium oxidizing (Anammox) sludge. Appl. Environ. Microbiol.63, 2446-2448.

[16] Van de Graaf, A.A., de Bruijn, P., Robertson, L.A., Jetten, M.S.M., Kuenen, J.G., 1996. Autotrophic growth of anaerobic ammonium oxidizing microorganisms in a fluidized bed reactor. Microbiology.142, 2187 -2196. 